\title{
Osteomyelitis: an overview of antimicrobial therapy
}

\author{
Diana Gomes ${ }^{1}$, Margarida Pereira ${ }^{2}$, Ana Francisca Bettencourt ${ }^{1, *}$ \\ ${ }^{1}$ Research Institute for Medicines and Pharmaceutical Sciences (iMed.UL), Faculty of Pharmacy, University of Lisbon, Lisbon, \\ Portugal, ${ }^{2}$ Santa Cruz Hospital, Lisbon, Carnaxide, Portugal
}

\begin{abstract}
Osteomyelitis is an inflammatory bone disorder caused by infection, leading to necrosis and destruction of bone. It can affect all ages, involve any bone, become a chronic disease and cause persistent morbidity. Treatment of osteomyelitis is challenging particularly when complex multiresistant bacterial biofilm has already been established. Bacteria in biofilm persist in a low metabolic phase, causing persistent infection due to increased resistance to antibiotics. Staphylococcus aureus and Staphylococcus epidermidis are the most common causative organism responsible for more than $50 \%$ of osteomyelitis cases. Osteomyelitis treatment implies the administration of high doses of antibiotics (AB) by means of endovenous and oral routes and should take a period of at least 6 weeks. Local drug delivery systems, using non-biodegradable (polymethylmethacrylate) or biodegradable and osteoactive materials such as calcium orthophosphates bone cements, have been shown to be promising alternatives for the treatment of osteomyelitis. These systems allow the local delivery of $\mathrm{AB}$ in situ with bactericidal concentrations for long periods of time and without the toxicity associated with other means of administration. This review examines the most recent literature evidence on the causes, pathogeneses and pharmacological treatment of osteomyelitis. The study methodology consisted of a literature review in Google Scholar, Science Direct, Pubmed, Springer link, B-on. Papers from 1979 till present were reviewed and evaluated.
\end{abstract}

Uniterms: Osteomyelitis/pharmacological treatment. Osteomyelitis/antimicrobial therapy. Staphylococcus aureus/presence/Osteomyelitis. Antibiotics/use/osteomyelitis treatment.

\begin{abstract}
A osteomielite é um processo inflamatório do tecido ósseo, de origem infecciosa, que resulta em destruição inflamatória, necrose e formação de novo osso. Pode aparecer em qualquer idade, afetar qualquer osso e tornar-se uma doença crônica com morbidade persistente. Apesar dos progressos na quimioterapia infecciosa, o tratamento da osteomielite é caro e difícil, em particular quando associada à presença de biofilmes bacterianos, especialmente de Staphylococcus aureus e Staphylococcus epidermidis. O tratamento da osteomielite inclui a administração de doses elevadas de antibióticos (AB) por via endovenosa e oral, durante um período de pelo menos 6 semanas. Os sistemas de veiculação localizada de fármacos, utilizando materiais não biodegradáveis (polimetilmetacrilato) ou biodegradáveis e osteoativos como os cimentos ósseos de ortofosfatos de cálcio e vidro bioativo, surgiram como uma alternativa promissora para o tratamento da osteomielite. Estes sistemas permitem a veiculação de AB in situ com concentrações bactericidas por longos períodos de tempo e sem a toxicidade associada às outras vias de administração. O presente trabalho propõe uma revisão da literatura relativa às causas, à patogenia e ao tratamento farmacológico da osteomielite. A metodologia do estudo da revisão consistiu numa pesquisa bibliográfica, nas bases de dados Google Scholar, Science Direct, Pubmed, Springer link, B-on. Foram revistos e analisados diversos artigos publicados desde o ano de 1979.
\end{abstract}

Unitermos: Osteomielite/tratamento farmacológico. Osteomielite/terapia antimicrobial. Staphylococcus aureus/presença/osteomielite. Antibióticos/uso/tratamento da osteomielite.

\footnotetext{
*Correspondence: A. F. Bettencourt. Faculdade de Farmácia, Universidade de Lisboa. Av. Prof. Gama Pinto, 1600-083 - Lisboa, Portugal. E-mail: asimao@ff.ul.pt
} 


\section{INTRODUCTION}

Osteomyelitis known since antiquity was first described by Chassaignac in 1852 (Lew, Waldvogel, 1997; Lindfors et al., 2010). The word "osteomyelitis" is derived from the ancient Greek words osteon (meaning bone) and muelinos (meaning marrow) and simply means an infection of the medullar portion of the bone. Common medical literature extends its definition to an inflammatory process of the entire bone including the cortex and the periosteum, accompanied by bone destruction and caused by an infecting organism (Lew, Waldvogel, 2004).

Osteomyelitis is a disease in transition, with ongoing changes in predisposing factors, causative organisms and treatment (Tice et al., 2003a). It affects both adults and children. Patients with certain conditions such as intravenous drug users, decubitus ulcers, surgery, trauma, immunosuppression, immune diseases (i.e. rheumatoid arthritis), diabetes mellitus, smoking, malnutrition, malignancy, extremes of age, chronic hypoxia, and renal or hepatic failure are at increased risk of osteomyelitis (Chihara, Segreti, 2010; Eid, Berbari, 2012).

Prognosis of osteomyelitis is largely dependent on the mechanism of infection, the virulence of the infecting organism and the immune status and comorbid conditions of the patient (Tice et al., 2003b; Chihara, Segreti, 2010). The mortality rate is low, unless associated with sepsis or when a serious underlying medical condition is present. However, morbidity can be significant, and may include localized dissemination to soft tissues and joints associated with it (Lew, Waldvogel, 2004; Chihara, Segreti, 2010; McNally, Nagarajah, 2010).

Osteomyelitis is a disease which is heterogeneous in its pathophysiology, clinical presentation and management. It is felt to be one of the most difficult-to-treat infectious diseases (Sia, Berbari, 2006).

It continues to be a frequent indication for the use of intravenous antibiotic therapy as well as a major healthcare cost item (Tice et al., 2003a). Carrier systems that deliver antibiotics locally are widely-used experimentally and clinically to treat osteomyelitis because they can provide higher concentrations of drugs at the infected site (Zhang et al., 2010).

Osteomyelitis remains a severe problem worldwide, causing plenty of hospital admissions and entailing considerable expense (Frank et al., 2011). This review focuses on current knowledge of the disease and the progress being made in antimicrobial treatment including the use of local drug delivery systems.

\section{TERMINOLOGY}

Acute osteomyelitis is an infection characterized by edema, locally decreased blood supply and pus formation. The term is often used interchangeably with hematogenous osteomyelitis and refers to osteomyelitis before osteonecrosis has occurred (Lew, Waldvogel, 2004; Chihara, Segreti, 2010). Acute osteomyelitis can develop after bacteremia, mostly in prepubertal children and in elderly patients (Lew, Waldwogel, 2011).

Untreated or due to treatment failure, the infection can progress to a more chronic phase. Chronic osteomyelitis is defined as bone infection in the presence of osteonecrosis. It is associated with formation of a large area of devascularized dead bone, a sequestrum (Lew, Waldvogel, 2004; Chihara, Segreti, 2010; Lindfors et al., 2010).

\section{PATHOGENIC MECHANISM OF INFECTION}

Experimental animal models of bone infection have revealed that bone is highly resistant to infection. Thus, osteomyelitis arises only when there is a large organism inoculation, trauma leading to bone damage, or the presence of foreign material (Eid, Berbari, 2012).

The pathophysiology of osteomyelitis is multifactorial and begins with spread of the organism. Bacteria may reach the bone by hematogenous seeding, direct inoculation, or airborne contamination (Gogia et al., 2009). Fungal osteomyelitis is more likely to result from disseminated fungal infection than direct inoculation of the bone (Eid, Berbari, 2012).

Based upon the pathogenic mechanisms of infection, various types of osteomyelitis can be grouped according to the source of the infection (Lew, Waldvogel, 2004):

1) Osteomyelitis secondary to a contiguous focus of infection (e.g, after trauma, surgery, or insertion of a prosthetic joint);

2) Osteomyelitis secondary to a contiguous focus of infection associated with vascular insufficiency, primarily occurring in patients with diabetes mellitus and/or peripheral vascular disease (Hartemann-Heurtier, Senneville, 2008; Lavery et al., 2009);

3) Osteomyelitis following hematogenous spread of infection, which is the major mechanism in vertebral osteomyelitis and in children (Macnicol, Watts, 2005; Labbé et al., 2010; Zimmerli, 2010; Pääkkönen, Peltola, 2011).

Whatever the source of infection, once an organism reaches the bone it causes acute inflammation. Bacteria have various different mechanisms to facilitate cell-cell and cellimplant adhesion (Gogia et al., 2009; Montanaro et al., 2011). 
Certain major causes of infection, such as Staphylococcus aureus, adhere to bone by expressing receptors (adhesins) for components of bone matrix (fibronectin, laminin, collagen, and bone sialoglycoprotein); the expression of the collagen-binding adhesion permits the attachment of the pathogen to cartilage (Lew, Waldvogel, 1997; Brady et al., 2006; Chihara, Segreti, 2010; Wright, Nair, 2010).

During acute infection, phagocytes attempt to contain invading microorganisms and, in the process, generate toxic oxygen radicals and release proteolytic enzymes that may lyse the surrounding tissues (Lew, Waldvogel, 1997).

Pus resulting from inflammatory response spreads into vascular channels, raising the intraosseous pressure and impairing blood flow. With the progression to a chronic state, the ischemic necrosis of bone results in the separation of devascularized fragments, which are called sequestrum (Lew, Waldvogel, 1997; Mcphee, Papadakis, 2007).
Microorganisms avoid the host defenses and antibiotics through a multiplicity of mechanisms including surviving in a dormant state inside osteoblasts, developing a biofilm, and acquiring a very slow metabolic rate (Brady et al., 2006; Montanaro et al., 2011; Eid, Berbari, 2012; Gould et al., 2012).

A schematic representation of the pathogenesis of osteomyelitis is shown in Figure 1.

\section{CAUSAL ORGANISMS}

The most common pathogens responsible for osteomyelitis in humans are Staphylococcus species, followed by Enterobacteriaceae and Pseudomonas species (Gogia et al., 2009). A summary of different etiology related to age and the predisposing conditions is shown in Table I.

Staphylococcus aureus is the most commonly isolated pathogen for both acute and chronic osteomyelitis
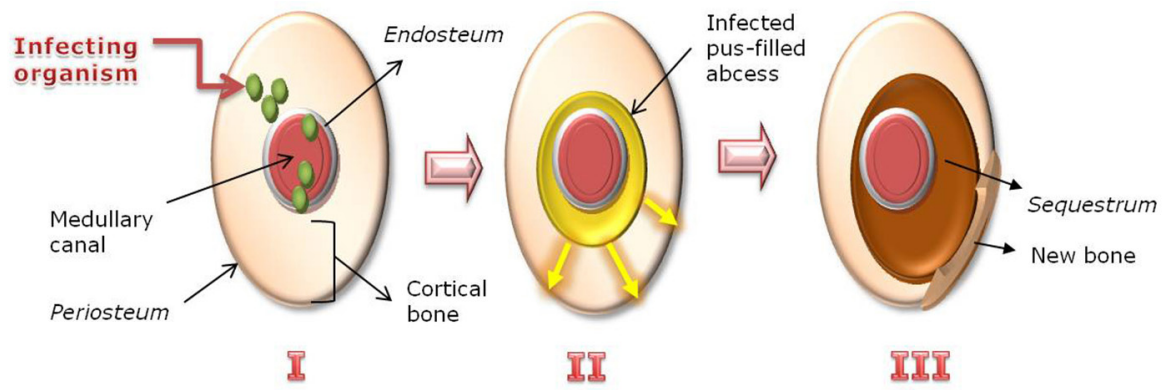

FIGURE 1 - Pathogenesis of osteomyelitis. I - A large inoculum of bacteria reaches the medular channel; II - (Acute state) Pus resulting from inflammatory response spreads into vascular channels; III - (Chronic state) Vascular channels are compressed and obliterated by the inflammatory process, and the resulting ischaemia also contributes to bone necrosis.

TABLE I - Most common isolated microorganisms in osteomyelitis are related to age and susceptibility factors (adapted from Lew, Waldvogel, 2004; Brook, 2008; McNally, Nagarajah, 2010; Chihara, Segreti, 2010; Jorge et al., 2010; Zimmerli, 2010; Eid, Berbari 2012)

\begin{tabular}{|c|c|}
\hline$\overline{\text { Age }}$ & Etiology \\
\hline Newborn babies & S. aureus, Enterobacter spp., Streptococcus (group A and B) \\
\hline Children & S. aureus, Enterobacter spp., Streptococcus (group B), Haemophilus influenzae \\
\hline Adults & S. aureus \\
\hline Susceptibility factors & Etiology \\
\hline Injectable drug users & S. aureus, $P$. aeruginosa, Serratia marcescens, Candida spp. \\
\hline Imunocompromised & $\begin{array}{l}\text { S. aureus, Bartonella henselae, Aspergillus spp., Mycobacterium avium complex, Candida } \\
\text { albicans }\end{array}$ \\
\hline Urinary infection & P. aeruginosa, Enterococcus spp. \\
\hline Spinal column surgery & S. aureus, coagulase-negative staphylococci, aerobic gram-negative bacilli \\
\hline Orthopedic fixation devices & S. aureus, coagulase-negative staphylococci, Propionibacterium spp. \\
\hline Hospitalization (nosocomial source) & Enterobacteriaceae, $P$. aeruginosa, Candida spp. \\
\hline $\begin{array}{l}\text { Diabetes mellitus, vascular } \\
\text { insufficiency, contaminated open } \\
\text { fracture }\end{array}$ & $\begin{array}{l}\text { Polimicrobial: S. aureus, Staphylococci coagulase negative, Streptococcus spp., } \\
\text { Enterococcus spp., Gram-negative bacilli, anaerobes }\end{array}$ \\
\hline
\end{tabular}


in all age groups (Jorge et al., 2010; Eid, Berbari, 2012). There has been an increase in methicillin-resistant $S$. aureus (MRSA) in recent years (Chihara, Segreti, 2010), due to rapid development of antimicrobial resistance and expression of virulence factors, regardless of the patient's immune status. Coagulase-negative staphylococci are often seen in association with foreign bodies, such as prosthetic joints (Chihara, Segreti, 2010).

Haemolytic streptococci are also responsible for bone infection (Darley, MacGowan, 2004).

Anaerobic bacteria as Bacteroides spp., anaerobic cocci, Fusobacterium spp., Propionibacterium acnes and Clostridium spp. have received increasing recognition in the bacteriology of osteomyelitis, although the exact prevalence of anaerobes in this disease is unknown (Brook, 2008; Jorge et al., 2010; Furustrand et al., 2012). Anaerobes may contribute to polymicrobial osteomyelitis in vasculopathic infection such as diabetic foot infection (Eid, Berbari, 2012).

Also, Gram-negative bacteria, such as Pseudomonas aeruginosa and Enterobacteriaceae have grown in importance as causative agents due to the increasing number of orthopedic surgeries with the use of implants and, especially, the rising number of high-energy traumas associated with open fractures, as a consequence of traffic accidents and war injuries (Chihara, Segreti, 2010; Carvalho et al., 2012).

Virtually any organism has the potential to cause osteomyelitis. For example in immunocompromised patients, pathogens such as Bartonella henselae, Aspergillus spp., Mycobacterium avium complex or Candida albicans may be isolated (Arias et al., 2004; Chihara, Segreti, 2010; Eid, Berbari, 2012).

\section{ANTIMICROBIAL THERAPY FOR OSTE- OMYELITIS}

\section{General considerations}

Several medical specialties are involved in the treatment of patients with osteomyelitis, including orthopaedic surgeons, microbiologists, and scientists in the fields of biology and biomechanics (Efstathopoulos et al., 2008). The primary goal of treatment is remission of the disease, which is defined as the absence of any sign of infection, in the initial or contiguous location, at least one year after the end of antimicrobial therapy (Chihara, Segreti, 2010).

The difference in pathophysiology of various types of osteomyelitis mandates specific therapeutic strategies aimed at the eradication of the infection while preserving bone integrity and function (Eid, Berbari, 2012; Moenster et al., 2012). Early antibiotic treatment, before extensive destruction of bone or necrosis, produces the best results and must be administered by the intravenous route for at least four (and usually six) weeks to achieve an acceptable rate of cure (Lew, Waldvogel, 1997). The initial choice of antibiotic inevitably depends on the causal pathogen and its susceptibility pattern. Antibiotics considered bactericidal against the infecting organisms are often considered necessary (Darley, MacGowan, 2004).

Acute osteomyelitis is usually successfully treated with intravenous antibiotics (Lew, Waldvogel, 2004; Darley, MacGowan, 2004).

The treatment of chronic osteomyelitis is more complicated and requires a multidisciplinary approach in 3 phases: surgical debridement, systemic antibiotic therapy for 4 to 6 weeks and local antibiotic delivery systems (Sánchez et al., 2001; Aslam, Darouiche, 2009; Mouzopoulos, 2011). The goal of surgical treatment is to convert an infection with dead bone to a situation with well-vascularized tissues that are readily penetrated by antibiotics, making prolonged drug treatment unnecessary (Mader et al., 1993).

Osteomyelitis surgical treatment is beyond the scope of the present review. Some recent data on the subject can be found (Lew, Waldvogel, 2004; Chihara, Segreti, 2010; Haidar et al., 2010; Malizos et al., 2010).

Next, we will discuss the classes of antibiotics used in oral and systemic antibiotic treatment and the use of local antibiotic delivery systems mainly in the management of chronic osteomyelitis.

\section{Oral and parenteral antibiotic treatment}

Parenteral antimicrobial therapy remains the mainstay of antimicrobial therapy for osteomyelitis and is commonly used for 4-6 weeks. An early switch to oral administration is appropriate for antibiotics with good bioavailability and bone penetration (Lew, Waldvogel, 2004; Eid, Berbari, 2012). Combined parenteral and oral regimens are usually used (Calhoun, Manring, 2005). The advantages and disadvantages of oral and parenteral routes are summarized in Table II.

\section{Beta-lactams and lincosamides}

Intravenous beta-lactams antibiotics (i.e. penicillins and cephalosporins) were commonly used to treat osteomyelitis due to their efficacy and relative safety when given for a prolonged period of time (Eid, Berbari, 2012). As new oral regimens become available, and the prevalence of MRSA increases, intravenous beta-lactams are likely to become less widely used for osteomyelitis 
TABLE II - Advantages and disadvantages of parenteral, oral and local antibiotic therapy (adapted from Gitelis, Brebach, 2002; Ambrose et al., 2003; Lazzarini et al., 2005)

\begin{tabular}{lll}
\hline $\begin{array}{l}\text { Therapy } \\
\text { Type }\end{array}$ & Advantages & Disadvantages \\
\hline Parenteral & $\begin{array}{l}\text { - Delivery of antibiotic to areas that cannot be reached } \\
\text { with oral therapy }\end{array}$ & - Often requires hospitalization \\
& - Choice of a large set of agents & - Lack of patient compliance \\
& - Arrest or eradication of infection in most cases (in & - Even with prolonged intravenous antibiotic therapy \\
& conjunction with surgical debridement) & relapse of bone infection is not uncommon \\
& & - Expensive \\
\hline Oral & - Ease of administration & - Therapeutically unpredictable \\
& - Reduced duration of hospitalization and health care costs & - Capacity for replace the prolonged courses of \\
& & parenteral therapy is controversial \\
& - Avoid high serum concentrations of the antibiotic & - Limited choice of agents \\
\hline Local & - Deliver antibiotic directly to the infection site & - Lack of proven efficacy in good randomized clinical \\
& - Reduced duration of hospitalization and health care costs & \\
\hline
\end{tabular}

treatment (Eid, Berbari, 2012). Oral beta-lactams are more effective in pediatric osteomyelitis, as compared to adults, as is the rate of healing (Pawar, Bhandari, 2011). Oral cephalosporins, e.g., cephalexin, ceftriaxone are often used clinically. Once-daily administered drugs, such as ceftriaxone, are preferred, especially for outpatient therapy (Lazzarini et al., 2005). Also, clindamycin is a lincosamide antibiotic active against most gram-positive bacteria, has excellent oral bioavailability and high bone serum ratios and is currently given orally after initial intravenous treatment for 1 to 2 weeks (Calhoun, Manring, 2005; Pawar, Bhandari, 2011).

\section{Fluoroquinolones}

The fluoroquinolones have gained popularity in recent years because of their excellent oral bioavailability and bone penetration (Lew, Waldvogel, 2004).

Promising results have been demonstrated in several trials especially against Gram-positive, Gram-negative, and polymicrobial infections (Pawar, Bhandari, 2011). Extensive in vitro studies have demonstrated the role of the second generation fluoroquinolones like ciprofloxacin, ofloxacin, and pefloxacin against some Gram-positive organisms (Pawar, Bhandari, 2011). Yet, they have poor activity against Streptococcus spp., Enterococcus spp., and anaerobic bacteria (Calhoun, Manring, 2005).

The third-generation quinolone, levofloxacin, has improved Streptococcus spp. activity, but with minimal anaerobic coverage (Calhoun, Manring, 2005). The newer fourth-generation fluoroquinolones, gatifloxacin, moxifloxacin, and gemifloxacin cover many gram-positive and gram-negative organisms, and certain anaerobes. Never- theless, newer fluoroquinolones are not as active against P. aeruginosa as ciprofloxacin (Calhoun, Manring, 2005).

In general, quinolones efficacy against Enterobacteriaceae is undisputed, an advantage over conventional therapy for infections with $P$. aeruginosa, Serratia spp., and $S$. aureus has yet to be shown in controlled studies (Lew, Waldvogel, 2004). In addition, the widespread use of quinolones has led to the emergence of quinolone-resistant S. aureus strains (Pawar, Bhandari, 2011), therefore the use of a second agent in the treatment of $S$. aureus infection is advisable (Darley, MacGowan, 2004). Fluoroquinolones have also been reported to inhibit fracture healing, but the clinical significance of this observation is not known (Aslam, Darouiche, 2009).

\section{Rifampicin and fusidic acid}

Rifampicin, a broad-spectrum antimicrobial agent, achieves high intracellular levels and is one of the few antimicrobial agents that can penetrate biofilms and kill organisms in the sessile phase of growth (Aslam, Darouiche, 2009). Several studies have shown that oral treatment with rifampicin in combination with various antibiotics as ciprofloxacin, ofloxacin, or fusidic acid is effective in bone staphylococcal infections in the presence of implants or prosthetic joints (Lew, Waldvogel, 2004; Pawar, Bhandari, 2011).

However, its utility could be limited due to the development of resistance, inability to tolerate due to sideeffects, and frequent drug interactions.

High serum concentrations, bactericidal levels in infected and sclerotic bone, good intracellular concentrations, and good activity against $S$. aureus are some of the 
advantages of fusidic acid. Like rifampicin, early development of resistance, is one of the prime limitations of fusidic acid, unless used in combination (Pawar, Bhandari, 2011). Rifampicin and fusidic acid are reasonable adjunctive agents for combination therapy (Aslam, Darouiche, 2009).

\section{Glicopeptides}

The only drugs with a constant efficacy against all the staphylococcal strains, and which have been extensively studied in the treatment of bone infections, are glycopeptides, in particular vancomycin (Yin et al., 2005; Courvalin, 2006). Vancomycin is used to treat MRSA and ampicillin-resistant Enterococcus species (Eid, Berbari, 2012). Unfortunately, resistance to this antibiotic has already been recognized as a major problem in the treatment of Gram-positive pathogens and increasing data suggest that vancomycin is losing its clinical and microbiological potency. Increased prevalence of vancomycin-resistant $S$. aureus (VRSA), vancomycin-resistant enterococci (VRE) is already limiting its usage (Rice, 2006; Moise et al., 2009; Pawar, Bhandari, 2011; Vilhena, Bettencourt, 2012). Moenster et al. (2012) states that despite adequate dosing, $30 \%$ to $50 \%$ of patients experience infection recurrence within 12 months.

\section{New agents}

Newer antibiotics with high bone penetration such as linezolid, daptomycin and tigecycline are promising for treating osteomyelitis due to MRSA in patients who display intolerance or poor response to vancomycin but must be further tested in clinical trials (Lazzarini et al., 2005; Aslam, Darouiche, 2009; Pawar, Bhandari, 2011). A good review on the topic was recently published by Pawar and Bhandari (2011).

Linezolid, which can be administered either orally or intravenously, represents a new class of antibiotic with no cross-resistance to other antibiotics. It is active against Gram-positive organisms including VRE (E. faecium and E. faecalis) and MRSA (Darley, MacGowan, 2004; Calhoun, Manring, 2005). It has been proved effective for treating serious infections, including osteomyelitis (Calhoun, Manring, 2005). Long-term safety and efficacy data needs to be produced in bone and joint infections, since they are lacking. Additionally, no large randomized trials have been published on the use of linezolid for orthopaedic infections (Pawar, Bhandari, 2011).

Daptomycin is a novel parenteral cyclic lipopeptide with bactericidal activity against multi-drug resistant Gram-positive organisms commonly found in osteomyelitis, even when the other first-line drugs have failed (Calhoun, Manring, 2005; Lamp et al., 2007; Pawar, Bhan- dari, 2011; Vilhena, Bettencourt, 2012). Preliminary data suggests that daptomycin penetrates bone well and can be a potential therapeutic option for patients with MRSA or VRE osteomyelitis (Vilhena, Bettencourt, 2012). However, no randomized and controlled trials comparing the effectiveness and safety of daptomycin with other antibiotics used to treat bone and joint infections have been completed (Lamp et al., 2007; Pawar, Bhandari, 2011).

In addition, case reports suggest the potential for quinupristin-dalfopristin the first parenteral streptogramin and tigecycline, a novel parenteral glycylcycline to cure chronic osteomyelitis, but clinical data are limited (Fraimow, 2009; Kaya et al., 2011; Pawar, Bhandari, 2011). Long-term safety and efficacy data needs to be produced with regard to the use of these promising newer agents for treating osteomyelitis due to MRSA and vancomycin-resistant Enterococcus (VRE).

An overview of the potential choices of antimicrobial agents for commonly encountered microorganisms in osteomyelitis and preferred routes of administration are listed in Table III.

\section{Local Antibiotic Therapy}

Even with prolonged intravenous antibiotics, there is a significant relapse rate in the treatment of chronic osteomyelitis. To supplement oral and systemic antibiotics, local antibiotic delivery has been tried for many years (Gursel et al., 2001; Gitelis, Brebach, 2002; Nair et al., 2011).

The in situ implantation of a local antibiotic delivery system works to obliterate bacteria in the area as well as to reduce the dead space in the bone (Nair et al., 2011). Its use results in a lower serum antibiotic concentration than that associated with systemic administration, thereby reducing toxicity-related side-effects (Joosten et al., 2005; Samuel et al., 2012) (Table II).

Considering the most commonly described microbes causing chronic osteomyelitis, the most widely acceptable antimicrobial agents in local delivery systems are amino glycosides and to a lesser extent various beta-lactam agents and quinolones. However, a combination therapy of antibiotics is useful to reduce the toxicity of individual agents, to prevent the emergence of resistance and to treat mixed infections involved in osteomyelitis (Nandi et al., 2009).

The local delivery of antibiotics in the treatment of osteomyelitis has been used for decades regardless of the controversy over its effectiveness (Gitelis, Brebach, 2002).

To retain an appropriate antibiotic level, several drug delivery systems have been developed in the treatment of chronic osteomyelitis (Gitelis, Brebach, 2002). Generally, 
TABLE III - Antimicrobial therapy of osteomyelitis in adults for selected organisms (Chihara, Segreti, 2010; Sia, Berbari, 2010; Carvalho et al., 2012; Eid, Berbari, 2012)

\begin{tabular}{|c|c|c|}
\hline Microorganisms & First choice & Alternative choice \\
\hline $\begin{array}{l}\text { Staphylococci } \\
\text { Penicillin-sensitive }\end{array}$ & $\begin{array}{l}\text { Penicillin-G, 3-4 MU IV q } \\
4 \text { h for 4-6 wks }\end{array}$ & $\begin{array}{l}\text { Ceftriaxone, 1-2 g IV q } 24 \text { hrs or } \\
\text { clindamycin, } 900 \mathrm{mg} \text { IV q } 8 \text { h }\end{array}$ \\
\hline $\begin{array}{l}\text { Enterococci or streptococci with } \\
\text { penicillin } \mathrm{MIC} \geq 0.5 \mu \mathrm{g} / \mathrm{mL}\end{array}$ & $\begin{array}{l}\text { Penicillin-G, 3-4 MU (IV) q } \\
4 \mathrm{~h} \text { for 4-6 wks or } \\
\text { ampicillin, } 2 \mathrm{~g} \text { IV q } 4 \mathrm{~h} \text {; the addition of } \\
\text { gentamicin, } 1 \\
\mathrm{mg} / \mathrm{kg} \text { IV/IM q } 8 \mathrm{~h} \text { for } 1-2 \text { wks optional }\end{array}$ & $\begin{array}{l}\text { Vancomycin*, } 15 \mathrm{mg} / \mathrm{kg} \mathrm{IV} \mathrm{q} 12 \mathrm{~h} \text { for } \\
4-6 \mathrm{wks} \text {; the addition of gentamicin, } \\
1 \mathrm{mg} / \mathrm{kg} \text { IV/IM q } 8 \mathrm{~h} \text { for } 1-2 \mathrm{wks} \text { optional }\end{array}$ \\
\hline Enterobacteriaceae & Ceftriaxone, 1 -2 g IV q 24 h for 4-6 wks & $\begin{array}{l}\text { Ciprofloxacin, 500-750 mg PO q } 12 \mathrm{~h} \text { for } \\
4-6 \mathrm{wks}\end{array}$ \\
\hline $\begin{array}{l}\text { Pseudomonas aeruginosa or } \\
\text { Enterobacter spp. }\end{array}$ & $\begin{array}{l}\text { Cefepime, } 2 \text { g IV q } 12 \mathrm{~h} \text { for } 4-6 \text { wks or } \\
\text { meropenem, } 1 \text { g IV q } 8 \text { h for 4-6 wks }\end{array}$ & $\begin{array}{l}\text { Ciprofloxacin, } 750 \mathrm{mg} \text { PO q } 12 \mathrm{~h} \text { for } 4-6 \\
\text { wks, or ceftazidime, } 2 \text { g IV q } 8 \mathrm{~h}\end{array}$ \\
\hline $\begin{array}{l}\text { Mixed infections possibly involving } \\
\text { anaerobic bacteria }\end{array}$ & $\begin{array}{l}\text { Ampicillin/sulbactam, } 1.5-3 \mathrm{~g} \\
\text { IV q } 6 \mathrm{~h} \text { or piperacillin/tazobactam, } \\
3.375 \mathrm{~g} \text { IV q } 6 \mathrm{~h}\end{array}$ & $\begin{array}{l}\text { Carbapenem antibiotic or a combination of } \\
\text { fluoroquinolone plus clindamycin, } 900 \mathrm{mg} \\
\text { IV t.i.d or metronidazole, } 500 \mathrm{mg} \text { PO t.i.d }\end{array}$ \\
\hline Candida species & \multicolumn{2}{|c|}{$\begin{array}{l}\text { Amphotericin B } 0.5-1 \mathrm{mg} / \mathrm{kg} \text { daily for } 2-3 \mathrm{wks} \text { followed by fluconazole, } 6 \mathrm{mg} / \mathrm{kg} \mathrm{PO} / \mathrm{IV} \\
\text { daily for } 6-12 \mathrm{mo}\end{array}$} \\
\hline
\end{tabular}

Legend: h-hour; IM-intramuscular; IV-intravenous; q- every; mo-months; MU-million units; PO-per os; t.i.d- three times a day; wks-weeks. *pharmacokinetic monitoring (allows a better efficacy and minimal adverse effects)

the delivery vehicles may be classified as nonbiodegradable (or non-resorbable) and biodegradable (or resorbable) (Kanellakopoulou, Giamarellos-Bourboulis, 2000). In Table IV the main advantages and disadvantages of these two types of systems are outlined.

\section{Non-Biodegradable systems}

Antibiotic-impregnated polymethylmethacrylate (PMMA) beads and self-setting bone cement have been used to treat chronic osteomyelitis allowing the local delivery of high concentrations of antibiotics, while avoiding potential systemic side effects (Anagnostakos et al., 2006; Azi et al., 2010).

Gentamicin-impregnated beads were created by Klemm (1979) and were used to occupy dead space after debridement of infected bone related to chronic osteomyelitis. Klemm treated more than 100 patients in this fashion and a cure rate of 91.4\% was achieved (Azi et al., 2010; Schade, Roukis, 2010).
PMMA beads containing gentamicin have been approved for use in treatment of osteomyelitis in Europe, in the 1970s under the trade name of Septopal ${ }^{\circledR}$. Septopal beads have now been on the market for more than 30 years, a remarkably long time for a pharmacological product. It is still not accepted by the Food and Drug Administration (FDA) in the USA (Walenkamp, 2009).

Non-commercial preparations of beads prepared by surgeons themselves are also in use. Physician-made beads are individually manufactured by the surgeon using commercially available PMMA polymer mixed with a powdered antibiotic or can be created with the assistance of an individually made bead mold (Holtom, Patzakis, 2003) (Figure 2).

However, these types of beads have the disadvantage of a lack of thorough mixing of the antibiotic into the material and a lack of uniform size of bead, resulting in lower antibiotic availability (Kanellakopoulou, GiamarellosBourboulis, 2000). 
TABLE IV - Advantages and disadvantages of different type of antibiotic carrier systems (adapted from Gursel et al., 2001; Shirtliff et al., 2002; Gogia et al. 2009; Walenkamp, 2009; Campoccia et al., 2010)

\begin{tabular}{|c|c|c|}
\hline Carrier type & Advantages & Disadvantages \\
\hline 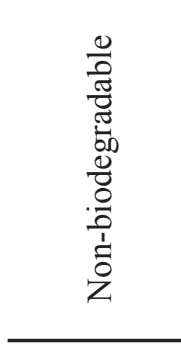 & $\begin{array}{l}\text { - Represent the current gold standard for local } \\
\text { antibiotic delivery } \\
\text { - Proven to be successful with several antibiotics } \\
\text { - Easy procedure for insertion in the body }\end{array}$ & $\begin{array}{l}\text { - Low biocompatibility, cytotoxic effects } \\
\text { - Second surgery may be needed to remove the cement } \\
\text { beads (which is costly and painful) } \\
\text { - Polymerization process could cause thermal damage and } \\
\text { neutralize the antibiotic } \\
\text { - Poor antibiotic elution properties } \\
\text { - Slow residual release of antibiotics for undefined periods; } \\
\text { risk of resistance }\end{array}$ \\
\hline 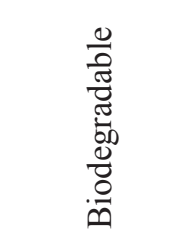 & $\begin{array}{l}\text { - Material properties can be adjusted to vary the } \\
\text { release rate of the antibiotic } \\
\text { - Osteoconductivity and osteoinductivity } \\
\text { - One-stage surgery } \\
\text { - Wider selection of antibiotics including } \\
\text { thermolabile ones }\end{array}$ & $\begin{array}{l}\text { - Do not form a firm bond with bone } \\
\text { - Initial burst of antibiotics to the infection site } \\
\text { - No large human trials have been published } \\
\text { - None of these materials has been approved for antibiotic } \\
\text { delivery in osteomyelitis treatment by the FDA }\end{array}$ \\
\hline
\end{tabular}
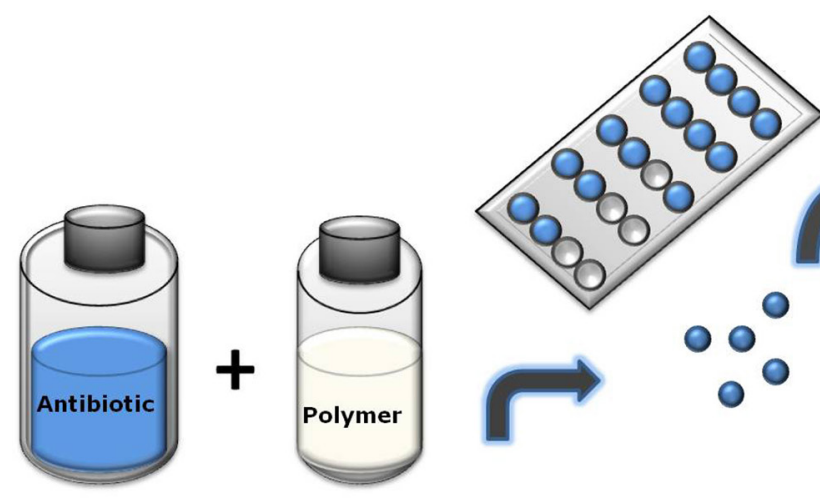

Antibiotic loaded beads

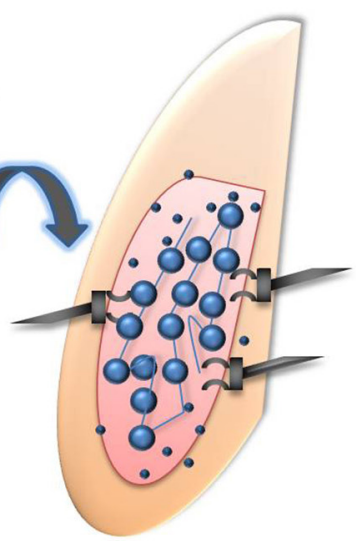

- Drug released

FIGURE 2 - The in situ implantation of antibiotic-impregnated beads, as a local antibiotic delivery system, works to obliterate bacteria in the area as well as to reduce the dead space in the bone.

Over the past three decades, numerous advantages with antibiotic-impregnated beads over systemic therapy have been recognized (Table IV) but their application is still controversial. Placement of these beads is a simple procedure and often performed at time of initial debridement of chronic osteomyelitis (Gogia et al., 2009). Local antibiotic treatment is also substantially less expensive than systemic therapy, which can cost hundreds of dollars per day in an outpatient setting and much more in the hospital setting. In spite of these advantages, bead placement generally requires a second operation for removal after the completion of antibiotic release. Another argument against its use is the lack of proof of efficacy in good randomized clinical trials (Walenkamp, 2009). The pros and cons regarding the use of gentamicin-containing PMMA beads were recently discussed by Barth et al. (2011).

Besides beads, the other form of antibiotic local delivery is by using PMMA bone cement, a powdered polymer mixed with a liquid monomer to form a solid structure.

Many antibiotics have been shown to maintain efficacy when mixed with PMMA bone cement. The most widely studied antibiotic is gentamicin, an excellent additive to PMMA due to its broad spectrum of action and good thermostability (Gogia et al., 2009; Azi et al., 2010). Tobramycin and vancomycin, both water soluble 
and available in powder form, have also been included in PMMA (Gogia et al., 2009). But the resistance to these routinely used antibiotics has led to an intensive search for alternative, more effective antibiotics to be loaded into PMMA bone cement. Marra et al. (2001) described the treatment with amphotericin B-loaded bone cement of a case of osteomyelitis due to Candida albicans in an adult who had undergone multiple revisions of a hip prosthesis. Efstathopoulos et al. (2008) evaluated the efficacy of grepafloxacin loaded acrylic bone cement (polymethylmethacrylate, PMMA) for the treatment of experimentally chronic osteomyelitis induced in rabbits. Just recently, Samuel et al. (2012) evaluated the bioactivity of meropenem loaded bone cement with possible application in Gram negative bone infections.

Presently, the major concern related to the use of PMMA-based local antibiotic delivery system refers to the risk of induction of antibiotic resistance due to their possible contribution to enhancing biofilm formation on the material and selecting resistant mutants (Campoccia et al., 2010).

Nevertheless, taking into account the numerous recently published in vitro and in vivo studies related to antibiotic loaded PMMA systems (Marra et al., 2001; Efstathopoulos et al., 2008; Samuel et al., 2012), it is expected they will remain in the near future an effective drug delivery system for local antibiotic therapy in osteomyelitis.

\section{Biodegradable systems}

In order to address some of the drawbacks of local delivery with PMMA, the use of local antibiotics from a biodegradable implant for osteomyelitis is an attractive alternative and has been actively investigated in recent years. Major advantages of these implants include obliteration of dead space, aid to bone repair, wider selection of antibiotics including thermolabile ones and no need for a second surgery for removal (Table IV) (Gitelis, Brebach, 2002).

A large number of biodegradable and biocompatible carrier materials such as bioceramics, polymers, bioglasses and composites have been tried in vitro and in vivo (Table $\mathrm{V})$ as possible methods for local antibiotic therapy of osteomyelitis. Interesting reviews on the subject can be found in Kanellakopoulou, Giamarellos-Bourboulis (2000) and Nandi et al. (2009).

Impregnation of antimicrobial agents within osteoconductive bioceramics (calcium sulphate, tricalcium phosphate or hydroxyapatite) has been proposed for the local management of osteomyelitis and to aid dead space management mainly for the delivery of aminoglicosides such as tobramycin (Nelson et al., 2002) and vancomycin (Mäkinen et al., 2005; Xie et al., 2009).
Besides bioceramics, other bioactive inorganic materials are being explored as silicate (Mäkinen et al., 2005; Lindfors et al., 2010) and borate-based bioglasses (Xie et $a l ., 2009)$ for the treatment of chronic osteomyelitis.

These bone-filling materials have the advantage of converting to a hydroxyapatite (HA)-type material, the main mineral constituent of bone, and bond strongly with bone and soft tissue in vivo, promoting osteogenesis on their surfaces (Mäkinen et al., 2005; Zhang et al., 2010).

An alternative approach that has also been tested in the local treatment of osteomyelitis is the use of biodegradable polymeric carriers such as lactid acid polymers (Garvin et al., 1994; Kanellakopoulou, Giamarellos-Bourboulis, 2000; Ambrose et al., 2003, 2004) and collagen (Riegels-Nielsen et al., 1995) especially for antibiotics such as ampicillin, tobramycin and gentamicin. Recently, an injectable degradable polymer, poly(sebacic-co-ricinoleic-ester-anhydride) containing gentamicin proved to be efficient histologically in the treatment of osteomyelitis (Brin et al., 2008).

Currently, one of the most promising strategies is to develop organic-inorganic hybrids or composite biomaterials providing excellent possibilities for improving the conventional drug delivery systems. In this sense, several biocomposites composed of biodegradable polymers such as chitosan poly(lactic-co-glycolic acid), poly(D,Llactide) or poly-e-caprolactone and inorganic materials like tricalcium phosphate, hydroxyapatite and bioactive glasses have been tried (Mäkinen et al., 2005; Alvarez et al., 2008; Miyai et al., 2008; Zhang et al., 2010), showing promising results for curing chronic osteomyelitis in animal models (Table V).

To our knowledge, no large human trials have been published and none of these materials has been approved for antibiotic delivery in osteomyelitis treatment by the FDA.

\section{CONCLUSIONS}

Osteomyelitis is a serious deep bone infection with significant morbidity and high rates of recurrence. The infection, caused by a variety of microbial agents (the most common being $S$. aureus) can arise from a variety of etiologies such as trauma, nosocomial infections or after implant replacement surgery. Despite advances in medical and surgical therapies, the management of osteomyelitis is an increasing challenge to clinicians due to the growing resistance to antibiotics.

Currently, the standard treatment of osteomyelitis includes debridement of infected tissues, dead space management, and 4 to 6 weeks of parenteral antibiotics. 
TABLE V - Example of studies exploring different biodegradable carriers materials to treat chronic osteomyelitis in animal model

\begin{tabular}{|c|c|c|c|c|c|}
\hline Class & Material & Antibiotic & Tested m.o. & $\begin{array}{l}\text { Animal } \\
\text { model }\end{array}$ & Reference \\
\hline \multirow{6}{*}{ 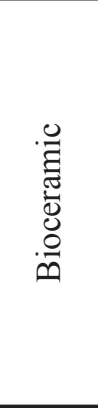 } & Calcium phosphate & Gentamicin & S. aureus & Rabbits & Joosten et al., 2004 \\
\hline & Calcium sulphate & Moxifloxacin & MRSA & Rabbits & $\begin{array}{l}\text { Kanellakopoulou et } \\
\text { al., } 2009\end{array}$ \\
\hline & Calcium sulphate & Tobramycin sulphate & S. aureus & Rabbits & Nelson et al., 2002 \\
\hline & Hydroxyapatite & Vancomycin & S. aureus & Rabbits & Shirtliff et al., 2002 \\
\hline & Hydroxyapatite & Gentamicin sulphate & S. aureus & Rats & $\begin{array}{l}\text { Korkusuz et al., } \\
1993\end{array}$ \\
\hline & Hydroxyapatite & Vancomycin & MRSA & Rabbits & Joosten et al., 2005 \\
\hline \multirow{6}{*}{ 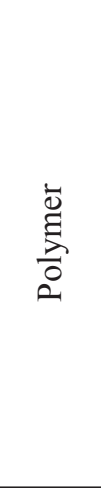 } & Collagen & Gentamicin & S. aureus & Rabbits & $\begin{array}{l}\text { Riegels-Nielsen et } \\
\text { al., } 1995\end{array}$ \\
\hline & PEG, PLGA & $\begin{array}{l}\text { Tobramycin, } \\
\text { Cefazolin }\end{array}$ & S. aureus & Rabbits & Ambrose et al., 2004 \\
\hline & Polyhydroxy-alkanoate & $\begin{array}{l}\text { Sulbactam, } \\
\text { cefoperazone, } \\
\text { ampicillin }\end{array}$ & S. aureus & Rabbits & Gursel et al., 2001 \\
\hline & Polylactide/polyglicolide & Gentamicin & S. aureus & Dogs & Garvin et al., 1994 \\
\hline & $\mathrm{P}(\mathrm{SA}-\mathrm{RA})$ & Gentamicin & S. aureus & Rats & Brin et al., 2008 \\
\hline & $\mathrm{P}(\mathrm{SA}-\mathrm{RA})$ & Gentamicin & S. aureus & Rats & Krasko et al., 2007 \\
\hline \multirow{3}{*}{ 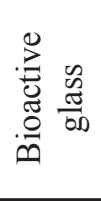 } & Borate & Vancomycin & MRSA & Rabbits & Xie et al., 2011 \\
\hline & Borate & Vancomycin & MRSA & Rabbits & Xie et al., 2009 \\
\hline & Boro-silicate & $\begin{array}{l}\text { Ceftriaxone-- } \\
\text { sulbactam }\end{array}$ & S. aureus & Rabbits & Kundu et al., 2011 \\
\hline \multirow{4}{*}{ 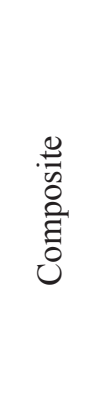 } & Chitosan, borate glass & Teicoplanin & S. aureus & Rabbits & Zhang et al., 2010 \\
\hline & PLGA, bioactive glass & Ciprofloxacin & $\begin{array}{l}\text { S. aureus, } \\
\text { S.epidermidis, E. coli, } \\
\text { P. aeruginosa }\end{array}$ & Rabbits & Mäkinen et al., 2005 \\
\hline & $\begin{array}{l}\text { Poly(D,L-lactide), } \\
\text { tricalcium-phosphate, } \\
\text { hydroxyapatite }\end{array}$ & Ciprofloxacin & S. aureus & Rabbits & Alvarez et al., 2008 \\
\hline & $\begin{array}{l}\text { Poly- } \varepsilon \text {-caprolactone, } \\
\text { tricalcium phosphate }\end{array}$ & Gatifloxacine & S. milleri, B. fragilis & Rabbits & Miyai et al., 2008 \\
\hline
\end{tabular}

Legend: m.o.-microorganism; MRSA-methicillin-resistant S. aureus; PEG-poly(ethylene glycol); PLGA-poly(DL-lactic-co-glycolic acid); P(SA-RA)-Poly(sebacic-co-ricinoleic-ester-anhydride).

Among the numerous antibiotics that have been reported to be useful in the treatment of osteomyelitis, vancomycin has been used for decades to treat MRSA associated infection. However poor vancomycin bone penetration and increasing rates of heteroresistance and glycopeptide tolerance have encouraged the search for newer agents, namely linezolid, daptomycin, quinupristin-dalfopristin and tigecycline.

Management of chronic osteomyelitis with the local delivery of antibiotics has the advantage of achiev- ing high antibiotic concentrations at the site of infection without the systemic toxicity associated with the parenteral route. The most commonly used non-biodegradable carrier material has long been PMMA in the form of beads or bone cement. A novel number of biodegradable carriers systems have been developed in recent years with promising clinical potential, combining local delivery of the drug with osteogenic potential. This is an emerging area of research with great potential in the near future to treat osteomyelitis. 


\section{ACKNOWLEDGEMENTS}

The authors thank Dr. Nuno Diogo, Head of Orthopaedic Department of Hospital Curry Cabral (Lisbon) for his motivation concerning the writing of the article.

The authors are grateful to Fundação para a Ciência e Tecnologia (Portugal) for financial support (PEst-OE/ SAU/UI4013/2011 and EXCL/CTM-NAN/0166/2012).

\section{DECLARATION OF INTEREST}

The authors report no conflicts of interest. The authors alone are responsible for the content and writing of the article.

\section{REFERENCES}

ALVAREZ, H.; CASTRO, C.; MOUJIR, L.; PERERA, A.; DELGADO, A.; SORIANO, I.; EVORA, C.; SANCHEZ, E. Efficacy of ciprofloxacin implants in treating experimental osteomyelitis. J. Biomed. Mater. Res. B. Appl. Biomater., v.85, n.1, p.93-104, 2008.

AMBROSE, C.G.; CLYBURN, T.A.; LOUDEN, K.; JOSEPH, J.; WRIGHT, J.; GULATI, P.; GOGOLA, G.R.; MIKOS, A.G. Effective Treatment of osteomyelitis with biodegradable microspheres in a rabbit model. Clin. Orthop. Relat. Res., v.421, p.293-299, 2004.

AMBROSE, C.G.; GOGOLA, G.R.; CLYBURN, T.A.; RAYMOND, A.K.; PENG, A.S.; MIKOS, A.G. Antibiotic Microspheres: Preliminary Testing for Potential Treatment of Osteomyelitis. Clin. Orthop. Relat. Res., v.415, p.279$285,2003$.

ANAGNOSTAKOS, K.; FÜRST, O.; KELM, J. Antibioticimpregnated PMMA hip spacers. Current status. Acta Orthop., v.77, n.4, p.628-637, 2006.

ARIAS, F.; MATA-ESSAYAG, S.; LANDAETA, M.E.; CAPRILES, C.H.; PÉREZ, C.; NÚÑEZ, M.J.; CARVAJAL, A.; SILVA, M. Candida albicans osteomyelitis: case report and literature review. Int. J. Infect. Dis., v.8, n.5, p.307314, 2004.

ASLAM, S.; DAROUICHE, R.O. Antimicrobial therapy for bone and joint infections. Curr. Infect. Dis. Rep., v.11, n.1, p.7-13, 2009.
AZI, M.L.; JUNIOR, M.K.; MARTINEZ, R.; PACCOLA, C.A.J. Bone cement and gentamicin in the treatment of bone infection: background and in vitro study. Acta Ortop. Bras., v.18, n.1, p.31-34, 2010.

BARTH, R.E.; VOGELY, H.C.; HOEPELMAN, A.I.; PETERS, E.J. To bead or not to bead? Treatment of osteomyelitis and prosthetic joint-associated infections with gentamicin bead chains. Int. J. Antimicrob. Agents, v.38, n.5, p.371375, 2011.

BRADY, R.A.; COSTERTON, J.W.; SHIRTLIFF, M.E. Osteomyelitis: clinical overview and mechanisms of infection persistence. Clin. Microbiol. Newsletter, v.28, n.9, p.65-72, 2006.

BRIN, Y.S.; GOLENSER, J.; MIZRAHI, B.; MAOZ, G.; DOMB, A.J.; PEDDADA, S.; TUVIA, S.; NYSKA, A.; NYSKA, M. Treatment of osteomyelitis in rats by injection of degradable polymer releasing gentamicin. J. Control. Release, v.131, n.2, p.121-127, 2008.

BROOK, I. Microbiology and management of joint and bone infections due to anaerobic bacteria. J. Orthop. Sci., v.13, n.2, p.160-169, 2008.

CALHOUN, J.H.; MANRING, M.M. Adult osteomyelitis. Infect. Dis. Clin. North Am., v.19, n.4, p.765-786, 2005.

CAMPOCCIA, D.; MONTANARO, L.; SPEZIALE, P.; ARCIOLA, C.R. Antibiotic-loaded biomaterials and the risks for the spread of antibiotic resistance following their prophylactic and therapeutic clinical use. Biomaterials, v.31, n.25, p.6363-6377, 2010.

CARVALHO, V.C.; OLIVEIRA, P.R.D.; DAL-PAZ, K.; DE PAULA, A.P.; FÉLIX, C.S.F.; LIMA, L.L.M. Gramnegative osteomyelitis: clinical and microbiological profile. Braz. J. Infect. Dis., v.16, n.1, p.63-67, 2012.

CHIHARA, S.; SEGRETI, J. Osteomyelitis. Dis. Mon., v.56, n.1, p.5-31, 2010 .

COURVALIN P. Vancomycin resistance in gram-positive cocci. Clin. Infect. Dis., v.42, suppl.1, p.S25-S34, 2006.

DARLEY, E.S.; MACGOWAN, A.P. Antibiotic treatment of gram-positive bone and joint infections. J. Antimicrob. Chemother., v.53, n.6, p.928-935, 2004. 
EID, A.J.; BERBARI, E.F. Osteomyelitis: a review of pathophysiology, diagnostic modalities and therapeutic options. J. Med. Liban., v.60, n.1, p.51-60, 2012.

EFSTATHOPOULOS, N.; GIAMARELLOS-BOURBOULIS, E.; KANELLAKOPOULOU, K.; LAZARETTOS, I.; GIANNOUDIS, P.; FRANGIA, K.; MAGNISSALIS, E.; PAPADAKI, M.; NIKOLAOU, V.S. Treatment of experimental osteomyelitis by methicillin resistant Staphylococcus aureus with bone cement system releasing grepafloxacin. Injury, v.39, n.12, p.1384-1390, 2008.

FRAIMOW, H.S. Systemic Antimicrobial therapy in osteomyelitis. Semin. Plast. Surg., v.23, n.2, p.90-99, 2009.

FRANK, D.; MONTSKO, G.; JURICSKAY, I.; BORSICZKY, B.; CSEH, G.; KOCSIS, B.; NAGY, T.; NAGY, A.K.; KOVÁCS, G.L.; MISETA, A. Clindamycin release determined by high performance liquid chromatography from a novel low-cost local drug delivery system: a new potential treatment option for chronic osteomyelitis. J. Med. Liban., v.23, n.5, p.282-284, 2011.

FURUSTRAND, T.U.; CORVEC, S.; BETRISEY, B.; ZIMMERLI, W.; TRAMPUZ, A. Role of rifampin against propionibacterium acnes biofilm in vitro and in an experimental foreign-body infection model. Antimicrob. Agents Chemother., v.56, n.4, p.1885-1891, 2012.

GARVIN, K.; MIYANO, J.; ROBINSON, D.; GIGER, D.; NOVAK, J.; RADIO, S. Polylactide/polyglycolide antibiotic implants in the treatment of osteomyelitis. J. Bone Joint Surg Am., v.76, n. 10, p.1500-1506, 1994.

GITELIS, S.; BREBACH, G.T. The treatment of chronic osteomyelitis with a biodegradable antibiotic-impregnated implant. J. Orthop. Surg., v.10, n.1, p.53-60, 2002.

GOGIA, J.S.; MEEHAN, J.P.; CESARE, P.E.; JAMALI, A.A. Local antibiotic therapy in osteomyelitis. Semin. Plast. Surg., v.23, n.2, p.100-107, 2009.

GOULD, I.M.; DAVID, M.Z.; ESPOSITO, S.; GARAU, J.; LINA, G.; MAZZEI, T.; PETERS, G. New insights into meticillin-resistant Staphylococcus aureus (MRSA) pathogenesis, treatment and resistance. Int. J. Antimicrob. Agents, v.39, n.2, p.96-104, 2012.
GURSEL, I .; KORKUSUZ, F.; TURESIN, F. ; ALAEDDINOGLU, N.G.; HASIRCI, V. In vivo application of biodegradable controlled antibiotic release systems for the treatment of implant-related osteomyelitis. Biomaterials, v.22, n.1, p.73-80, 2001.

HAIDAR, R.; DER BOGHOSSIAN, A.D.; ATIYEH, B. Duration of post-surgical antibiotics in chronic osteomyelitis: empiric or evidence-based? Int. J. Infect. Dis., v.14, n.9, p.752-758, 2010.

HARTEMANN-HEURTIER, A.; SENNEVILLE, E. Diabetic foot osteomyelitis. Diabetes Metab., v.34, n.2, p.87-95, 2008

HOLTOM, P.D.; PATZAKIS, M. Newer methods of antimicrobial delivery for bone and joint infections. Instr. Course. Lect., v.52, p.745-749, 2003

JOOSTEN, U.; JOIST, A.; FREBEL, T.; BRANDT, B.; DIEDERICHS, S.; VON EIFF, C. Evaluation of an in situ setting injectable calcium phosphate as a new carrier material for gentamicin in the treatment of chronic osteomyelitis: studies in vitro and in vivo. Biomaterials, v.25, n.18, p.4287-4295, 2004.

JOOSTEN, U.; JOIST, A.; GOSHEGER, G.; LILJENQVIST, U.; BRANDT, B.; VON EIFF, C. Effectiveness of hydroxyapatite-vancomycin bone cement in the treatment of Staphylococcus aureus induced chronic osteomyelitis. Biomaterials, v.26, n.25, p.5251-5258, 2005.

JORGE, L.S.; CHUEIRE, A.G.; ROSSIT, A.R. Osteomyelitis: a current challenge. Braz. J. Infect. Dis., v.14, n.3, p.310$315,2010$.

KANELLAKOPOULOU, K.; GALANOPOULOSB, I.; SORANOGLOU, V.; TSAGANOS, T.; TZIORTZIOTI, V.; MARIS, I. PAPALOIS, A.; GIAMARELLOU, H.; GIAMARELLOS-BOURBOULIS, E.J. Treatment of experimental osteomyelitis caused by methicillin-resistant Staphylococcus aureus with a synthetic carrier of calcium sulphate (Stimulan ${ }^{\circledR}$ ) releasing moxifloxacin. Int. J. Antimicrob. Agents, v.33, n.4, p.354-359, 2009.

KANELLAK OPOULOU,K.; GIAMARELL O S BOURBOULIS, E.J. Carrier systems for the local delivery of antibiotics in bone infections. Drugs, v.59, n.6, p.1223$1232,2000$. 
KAYA, M.; SIMSEK-KAYA, G.; GÜRSAN, N.; KIREÇÇI, E.; DAYI, E.; GÜNDOGDU, B. Local treatment of chronic osteomyelitis with surgical debridement and tigecyclineimpregnated calcium hydroxyapatite: an experimental study. Oral Surg. Oral Med. Oral Pathol. Oral Radiol. Endod., v.113, n.3, p.340-347, 2011.

KLEMM, K. Gentamicin-PMMA-beads in treating bone and soft tissue infections. Zentralbl. Chir, v.104, n.14, p.934942, 1979.

KORKUSUZ, F.; UCHIDA, A.; SHINTO, Y.; ARAKI, N.; INOUE, K.; ONO, K. Experimental implant-related osteomyelitis treated by antibiotic- calcium hydroxyapatite ceramic composites. J. Bone Joint Surg., v.75, n.1, p.111$114,1993$.

KUNDU, B.; NANDI, S.K.; KUMAR, S.; DASGUPTA, S.; DATTA. S.; MUKHERJEE, P.; ROY, S.; SINGH, A.K.; MANDAL, T.K.; DAS, P.; BHATTACHARYA, R.; BASU, D. Macro-to-micro porous special bioactive glass and ceftriaxone-sulbactam composite drug delivery system for treatment of chronic osteomyelitis: an investigation through in vitro and in vivo animal trial. J. Mater. Sci. Mater. Med., v.22, n.3, p.705-720, 2011.

LABBÉ, J.; PERES, O.; LECLAIR, O.; GOULON, R.; SCEMAMA, P.; JOURDEL, F. Acute osteomyelitis in children: the pathogenesis revisited? Orthop. Traumatol. Surg. Res., v.96, n.3, p.268-275, 2010.

LAMP, K.C.; FRIEDRICH, L.V.; MENDEZ-VIGO, L.; RUSSO, R. Clinical experience with daptomycin for the treatment of patients with osteomyelitis. Am.J. Med., v.120, n.10, suppl.1, p.S13-S20, 2007.

LAVERY, L.A.; PETERS, E.J.; ARMSTRONG, D.G.; WENDEL, C.S.; MURDOCH, D.P.; LIPSKY, B.A. Risk factors for developing osteomyelitis in patients with diabetic foot wounds. Diabetes Res. Clin. Pract., v.83, n.3, p.347352, 2009.

LAZZARINI, L.; LIPSKY, B.A.; MADER, J.T. Antibiotic treatment of osteomyelitis: what have we learned form 30 years of clinical trials? Int. J. Infect. Diseases, v.9, n.3, p.127-138, 2005.

LEW, D.P.; WALDVOGEL, F.A. Osteomyelitis: current concepts. N. Engl. J. Med., v.336, n.14, p.999-1007, 1997.
LEW, D.P.; WALDVOGEL, F.A. Osteomyelitis. Lancet, v.364, n.9431, p.369-379, 2004.

LINDFORS, N.C.; HYVÖNEN, P.; NYYSSÖNEN, M.; KIRJAVAINEN, M.; KANKARE, J.; GULLICHSEN, E.; SALO, J. Bioactive glass S53P4 as bone graft substitute in treatment of osteomyelitis. Bone, v.47, n.2, p.212-218, 2010.

MACNICOL, M.F.; WATTS, A.C. Haematogenous osteomyelitis. Surgery, v.23, n.1, p.25-30, 2005.

MADER, J.T.; LANDON, G.C.; CALHOUN, J. Antimicrobial treatment of osteomyelitis. Clin. Orthop. Relat. Res., v.295, p.87-95, 1993.

MÄKINEN, T.J.; VEIRANTO, M.; LANKINEN, P.; MORITZ, N.; JALAVA, J.; TÖRMÄLÄ, P.; ARO, H.T. In vitro and in vivo release of ciprofloxacin from osteoconductive bone defect filler. J. Antimicrob. Chemother., v.56, n.6, p.10631068, 2005.

MALIZOS, K.N.; GOUGOULIAS N.E.; DAILIANA, Z.H.; VARITIMIDIS, S.; BARGIOTAS, K.A.; PARIDIS, D. Ankle and foot osteomyelitis: Treatment protocol and clinical results. Injury-Int. J. Care. Injured, v.41, n.3, p.285293, 2010.

MARRA, F.; ROBBINS, G.M.; MASRI, B.A.; DUNCAN, C.; WASAN, K.M.; KWONG, E.H.; JEWESSON, P.J. Amphotericin B-loaded bone cement to treat osteomyelitis caused by Candida albicans. Can. J. Surg., v.44, n.5, p.383386, 2001.

MCNALLY, M.; NAGARAJAH, K. Osteomyelitis. Orthop. Trauma, v.24, n.6, p.416-429, 2010.

MCPHEE, S.; PAPADAKIS, M. Current medical diagnosis and treatment. McGraw Hill editor, 2007. p.880-882.

MIYAI, T.; ITO, A.; TAMAZAWA, G.; MATSUNO, T.; SOGO, Y.; NAKAMURA, C.; YAMAZAKI, A.; SATOH, T. Antibiotic-loaded poly- $\varepsilon$-caprolactone and porous $\beta$-tricalcium phosphate composite for treating osteomyelitis. Biomaterials, v.29, n.3, p.350-358, 2008.

MOENSTER, R.P.; LINNEMAN, T.W.; FINNEGAN, P.M.; MCDONALD, J.R. Daptomycin compared to vancomycin for the treatment of osteomyelitis: a single-center, retrospective cohort study. Clin. Ther., v.34, n.7, p.15211527, 2012. 
MOISE, P.A.; NORTH, D.; STEENBERGEN, J.N.; SAKOULAS, G. Susceptibility relationship between vancomycin and daptomycin in staphylococcus aureus: facts and assumptions. Lancet Infect. Dis., v.9, n.10, p.617$624,2009$.

MONTANARO, L.; TESTONI, F.; POGGI, A.; VISAI, L.; SPEZIALE, P.; ARCIOLA, C.R. Emerging pathogenetic mechanisms of the implant-related osteomyelitis by Staphylococcus aureus. Int. J. Artif. Organs, v.34, n.9, p.781-788, 2011.

MOUZOPOULOS, G.; KANAKARIS, N.K.; KONTAKIS, G.; OBAKPONOVWE, O.; TOWNSEND, R.; GIANNOUDIS, P.V. Management of bone infections in adults: the surgeon's and microbiologist's perspectives. Injury-Int. J. Care Injured, v.42, suppl.5, p.S18-S23, 2011.

NAIR, M.B.; KRETLOW, J.D.; MIKOS, A.G.; KASPER, F.K. Infection and tissue engineering in segmental bone defects - a mini review. Curr. Opin. Biotechnol., v.22, n.5, p.721-725, 2011.

NANDI, S.K.; MUKHERJEE, P.; ROY, S.; KUNDU, B.; DE, D.K.; BASU, D. Local antibiotic delivery systems for the treatment of osteomyelitis - a review. Mat. Sci. Eng C., v.29, n.8, p.2478-2485, 2009.

NELSON, C.L.; MCLAREN, S.G.; SKINNER R.A.; SMELTZER M.S.; THOMAS J.R.; OLSEN, K.M. The treatment of experimental osteomyelitis by surgical debridement and the implantation of calcium sulfate tobramycin pellets. J. Orthop. Res., v.20, n.4, p.643-647, 2002.

PÄÄKKÖNEN, M.; PELTOLA, H. Antibiotic treatment for acute haematogenous osteomyelitis of childhood: moving towards shorter courses and oral administration. Int. J. Antimicrob. Agents, v.38, n.4, p.273-280, 2011.

PAWAR, D.; BHANDARI, P. Newer antibiotics for musculoskeletal infections. Indian J. Rheumatol., v.6, n.1, p.80-86, 2011.

RICE, L.B. Antimicrobial resistance in gram-positive bacteria. Am. J. Med., v.119, n.6, suppl.1, p.S11-S19, 2006.

RIEGELS-NIELSEN, P.; ESPERSEN, F.; HÖLMICH, L.R.; FRIMODT-MØLLER, N. Collagen with gentamicin for prophylaxis of postoperative infection - Staphylococcus aureus osteomyelitis studied in rabbits. Acta Orthop. Scand., v.66, n.1, p.69-72, 1995.
SAMUEL, S.; MATHEW, B.S.; VEERARAGHAVAN, B.; FLEMING, D.H.; SAMUEL, B.; CHITTARANJAN, S.B.; PRAKASH, J.A. In vitro study of elution kinetics and bio-activity of meropenem-loaded acrylic bone cement. $J$. Orthopaedics Traumatol., v.13, n.3, p.131-136, 2012.

SÁNCHEZ, E.; BARO, M; SORIANO, I.; PERERA, A.; ÉVORA, C. In vivo-in vitro study of biodegradable and osteointegrable gentamicin bone implants. Eur. J. Pharm. Biopharm., v.52, n.2, p.151-158, 2001.

SCHADE, V.L.; ROUKIS, T.S. The role of polymethylmethacrylate antibiotic-loaded cement in addition to debridement for the treatment of soft tissue and osseous infections of the foot and ankle. J. Foot Ankle Surg., v.49, n.1, p.55-62, 2010.

SHIRTLIFF, M.E.; CALHOUN, J.H.; MADER, J.T. Experimental osteomyelitis treatment with antibioticimpregnated hydroxyapatite. Clin. Orthop. Relat. Res., v.401, p.239-247, 2002.

SIA, I.G; BERBARI, E.F. Osteomyelitis. Best Pract. Res. Clin. Rheumatol., v.20, n.6, p.1065-1081, 2006.

TICE, A.D.; HOAGLUND, P.A; SHOULTZ, D.A. Risk factors and treatment outcomes in osteomyelitis. J. Antimicrob. Chemother, v.51, n.5, p.1261-1268, 2003a.

TICE, A.D.; HOAGLUND, P.A.; SHOULTZ, D.A. Outcomes of osteomyelitis among patients treated with outpatient parenteral antimicrobial therapy. Am. J. Med., v.114, n.9, p.723-728, 2003 b.

VILHENA, C.; BETTENCOURT, A. Daptomycin: a review of properties, clinical use, drug delivery and resistance. Mini. Rev. Med. Chem., v.12, n.3, p.202-209, 2012.

WALENKAMP, G.H.I.M. Self-mixed antibiotic bone cement: western countries learn from developing countries. Acta Orthop., v.80, n.5, p.505-507, 2009.

WRIGHT, J.A.; NAIR S.P. Interaction of staphylococci with bone. Int. J. Med. Microbiol., v.300, n.2-3, p.193-204, 2010.

XIE, Z.; LIU, X.; JIA, W.; ZHANG, C.; HUANG, W. Vancomycin-loaded bioactive borate glass for treatment of chronic osteomyelitis in rabbit. Zhongguo Xiu Fu Chong Jian Wai Ke Za Zhi, v.25, n.7, p.830-836, 2011. 
XIE, Z.; LIU, X.; JIA, W.; ZHANG, C.; HUANG, W.; WANG, J. Treatment of osteomyelitis and repair of bone defect by degradable bioactive borate glass releasing vancomycin. $J$. Controlled Release, v.139, n.2, p.118-126, 2009.

YIN, L.Y.; LAZZARINI, L.; Li, F.; STEVENS, C.M.; CALHOUN, J.H. Comparative evaluation of tigecycline and vancomycin, with and without rifampicin, in the treatment of methicillin resistant Staphylococcus aureus experimental osteomyelitis in a rabbit model. J. Antimicrob. Chemother., v.55, n.6, p.995-1002, 2005.
ZHANG, X.; JIA, W.; GU, Y.; XIAO, W.; LIU, X.; WANG, D.; ZHANG, C.; HUANG, W.; RAHAMAN, M.N.; DAY, D.E.; ZHOU, N. Teicoplanin-loaded borate bioactive glass implants for treating chronic bone infection in a rabbit tibia osteomyelitis model. Biomaterials, v.31, n.22, p.5865-5874, 2010.

ZIMMERLI, W. Vertebral osteomyelitis. N. Engl. J. Med., v.362, n.11, p.1022-1029, 2010.

Received for publication on $01^{\text {st }}$ August 2012 Accepted for publication on $09^{\text {th }}$ January 2013 
